\title{
Representações cômicas da República no contexto do Getulismo
}

\author{
Elio Chaves Flores \\ Universidade Federal da Paraíba
}

RESUMO

Neste artigo analiso as representações cômicas e discursivas da República e a trajetória política de Getúlio Vargas, a partir de uma narrativa que se assenta no método regressivo. Para isso, trabalhei com uma série de caricaturas publicadas em jornais e revistas na duração entre 1930 e 1954, confrontando a intertextualidade dessas imagens com alguns discursos satíricos e irônicos produzidos por memorialistas. Procuro demonstrar que há semelhança entre a inversão humorística e a textualidade da memória, quando inventam a respeito de seu tempo e dos outros imagens verossímeis.

Palavras-chave: República; representação cômica; cultura política.

\begin{abstract}
This article analyses the comic and discursive representations of the Brazilian Republic and Getúlio Vargas' political career, starting from a narrative constructed in the regressive method. For that, I worked with a series of cartoons published in newspapers and magazines in the span of time between 1954 and 1930, matching the intertextuality of these images with some of the satiric and ironic speeches produced by witnesses. It is demonstrated there is likeness between the comic inversion and the textuality of the memory, when they invent concerning their time and other ones, the verisimilitude of the images.

Key-words: Republic; comic representation; political culture.
\end{abstract}


A graça adora coisas baixas e não lhe desagradam as espinhosas, e gosta de vestes sórdidas.

Umberto Eco

\section{COMICIDADE E CRONOLOGIA}

As reflexões historiográficas e hipóteses de trabalho desenvolvidas neste artigo em torno da duração republicana marcada pelo "animal político" Getúlio Dornelles Vargas e seu derivado coletivo, o getulismo, procuram demonstrar que uma determinada cultura política não escapa ao patético e ao cômico registrados pelas narrativas visuais e textuais de caricaturistas e memorialistas. A verve satírica e o estilo irônico seriam, pois, dois elementos tropológicos de vital importância para a compreensão de certas tradições republicanas. Assim, as recorrências cômicas e discursivas entre a República e o espaço/tempo político de Getúlio/getulismo parecem ser elucidativas na charge de Théo (Djalma Pires Ferreira), "Os Sonhos do Proclamador", publicada na revista Careta em novembro de 1952, e que passo a descrever: as imagens do ato fundador ganham destaque, em primeiro plano, nas insígnias e vestimenta militar do velho general de barbas brancas que se apóia, indelevelmente, na espada da ordem e se mostra com o olhar patético diante da pergunta de um político que estava no comando republicano há mais de duas décadas. "Que tal a sua República?”, isto é, aquela de 1889, tem ares de uma pergunta distanciada, como se o autor da mesma já aguardasse pela resposta de um Deodoro fora do tempo, e que somente poderia resmungar um lacônico “irreconhecível...” (Fig. 1).

O fato de o "proclamador" aparecer na década de 50, em meio ao turbilhão nacionalista, permite introduzir a hipótese de que o chargista, na sua representação cômica da República, rompeu a concepção "ingenuamente cronológica da experiência do tempo". Neste sentido, seguindo a reflexão de Pierre Bordieu, empreenderei uma análise regressiva entre o cômico e o tempo da política, pois a imagem que escolhi como epígrafe - a República entre Deodoro e Getúlio Vargas -, leva-me a postular que o "agente se temporaliza no próprio ato pelo qual transcende o presente imediato na direção do futuro implicado no passado do qual seu habitus é o produto; ele produz o tempo na antecipação prática de um 'por-vir' que é ao mesmo tempo atualização prática do passado"”.

A perspectiva regressiva trabalha com uma dimensão temporal que supera, no meu entender, as periodizações que vão desde a Revolução de 30 até a morte 


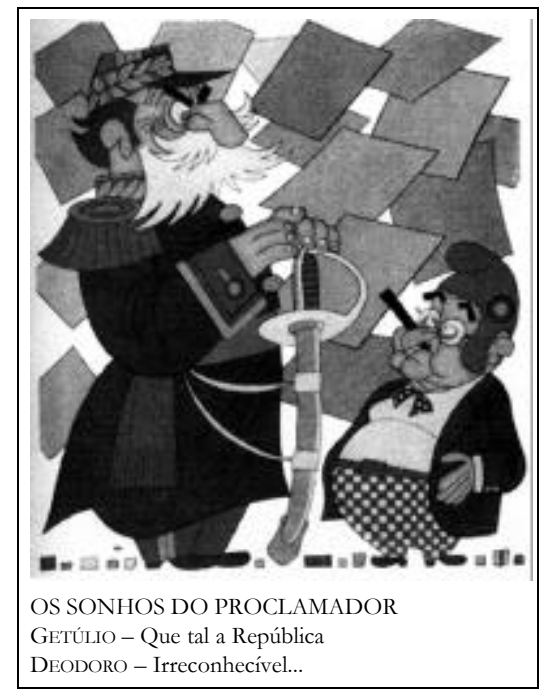

FIG. 1 - Théo. "Os sonhos do proclamador". Careta. Rio de Janeiro, 15/11/1952.

de Getúlio Vargas, em 1954. E se postulo que não existe mais um tempo linear ordenado por vínculos causais, então admito também que as consequências podem atuar sobre suas próprias causas. Com efeito, não me afastaria do pensamento histórico na medida em que se retira da comicidade o fenômeno da "história pública", e que, segundo Paul Ricouer, "tentamos compreender o sentido depois de ela ter acontecido, no estilo da retrospecção, ou até da retrodicção"’.

A ironia à linearidade temporal - as fases da República -, seria retratada por Érico Veríssimo, quando se refere ao "começo" do Estado Novo: “e um belo dia, em novembro de 37, a nação foi surpreendida com a notícia de um coup d'état espetacularmente bem-sucedido. Getúlio Vargas fora derrubado por Getúlio Vargas"'. Isso não soaria estranho a um estrangeiro que via a coisa pública brasileira além do "cômico Certificado de Origem para a Tia de Charly" no tempo de supostas rupturas insurrecionais: "Os políticos no Brasil republicano podem errar, e podem também cair da graça. Mas não caem do poder.” Ernest Hambloch, cônsul inglês no Brasil, iria mais além na ironia, pelo próprio título que atribuiu ao seu livro: Sua Majestade o Presidente do Brasil, com primeira edição datada de 1936. Outro ironista que brinca com a cronologia da República é o Barão de Itararé: "Em 1889 foi proclamada a República, a qual foi passando por muitos estados de evolução, entre os quais podemos citar o estado de sítio, o estado de emergência, o estado de guerra, o Estado Novo, que culminou, afinal, no estado a que chegamos." 4 
Deste modo, ver as imagens cômicas da República pelo getulismo seria, na verdade, aprofundar-se na problemática da cultura política brasileira contemporânea a partir de uma trajetória pragmatista, em que o tempo de Vargas estaria para a República como as "estruturas estão para os textos e culturas", ou como os "esqueletos estão para os corpos". Não seria arcaísmo dizer que um homem de ação pressupõe o fazer-se da "ciência do Estado" em meio aos dilemas do bem-estar republicano e dos interesses privados. ${ }^{5} \mathrm{Em}$ conseqüência, o procedimento para penetrar no conjunto de caricaturas e memórias que passo a discutir aproxima-se daquilo que Bakhtin definiu como "método histórico-alegórico", que consiste em desvendar, por entre as imagens performadas, tramas de acontecimentos que, de uma forma ou de outra, sedimentaram universos simbólicos e fomentaram a cultura política da República.

\section{O CÔMICO DO TRÁGICO}

O mês de agosto de 1954 colocou a República diante de uma orfandade inusitada: o suicídio do presidente, a comoção popular, as manchetes garrafais nas páginas da imprensa diária e o patético que tomou conta da oposição pareciam dar, aos acontecimentos de agosto, a atmosfera de um "tempo de catástrofes". Ao rememorar os episódios, alguns intelectuais fizeram questão de dar uma conotação de ironia mórbida à narrativa. Para Villas-Bôas Corrêa, um expoente da imprensa política, "a cidade ardeu em incêndios, desatinou-se no quebra-quebra e na pilhagem, até que se exauriu o ímpeto da desforra". E prosseguiu o homem, que lembra, ao narrar numa objetividade jornalística: “(...) só então a multidão encontrou-se para chorar o suicida que aplicara seu derradeiro golpe político. Um golpe de mestre". Ainda mais mordaz seria o teatrólogo Nelson Rodrigues em suas memórias: "todas as emissoras estavam alucinadas. Sentei-me, num canto; e pensava: - 'Vai começar a guerra civil'. (...) Eu continuava sonhando com uma guerra de secessão, com os brasileiros bebendo o sangue uns dos outros. Mas não pode haver secessão quando existe uma unanimidade. (...) Carlos Lacerda era o assassino de um suicida. E a unanimidade a exibir a sua face escavada e hedionda". A memória rodrigueana captou, então, uma imagem derradeira: “o cadáver de Getúlio ainda estava quente quando a Última Hora lançou a sua edição especial. Pode-se dizer que Vargas acabou de agonizar em nossa primeira página". Tivemos, portanto, dimensões temporais que "duram" no imaginário: o tempo de agosto, catastrófico e trágico, de uma República na qual o "mundo parecia estranho e hostil", com protestos populares invertendo e colocando às avessas "a lógica que anima os foliões"; e o tempo da memória, catártico, sardônico e risonho, de uma República imagem de si mesma, cujos protagonistas seriam os inventores de uma "comédia de absurdos". Foi o próprio Nelson Rodrigues quem 
sugeriu esta metáfora, quando lembrou que "o tempo passou e o tempo deu ao que parecia sublime um perverso e fatal toque humorístico".

Talvez tenha sido a caricaturista Hilde Weber quem melhor traçou o momento agonístico da República, no agosto de 1954, através de desenhos sucessivos para o jornal de Carlos Lacerda, a Tribuna da Imprensa. Destaco a imagem de Getúlio Vargas, pequenino, sentado na "monárquica" cadeira da presidência da República, praticamente em chamas, cuja imagem historiográfica remete à queima dos hereges. Vargas vivia um verdadeiro inferno político, o que também não deixa de ser uma alusão ao "fogo do inferno". Numa atitude de resistência a qualquer abjuração, o presidente sustenta uma atitude irascível: "Daqui não saio..." (Fig. 2). Lugar da República que somente sairia, conforme outra charge da autora, pela fumaça de seu tradicional charuto, formando o espírito que desencarnava da sua materialidade. Não por acaso, o álbum de caricaturas de Hilde Weber se chamaria $\mathrm{O}$ Brasil em Charge, no qual se destacam as suas notáveis imagens getulistas com os cabelos arrebitados.

Penso que a caricatura destaca a idiossincrasia de uma imagem cara ao regime: ao colocar o presidente impassível no "trono" presidencial, a autora trabalha situações tensas e dramáticas, no caso universais, em termos de luta pelo poder político, e ao mesmo tempo cômicas porque remete-as ao tempo e à arqueologia da República. A visibilidade da cadeira republicana em contraste com o seu ocu-

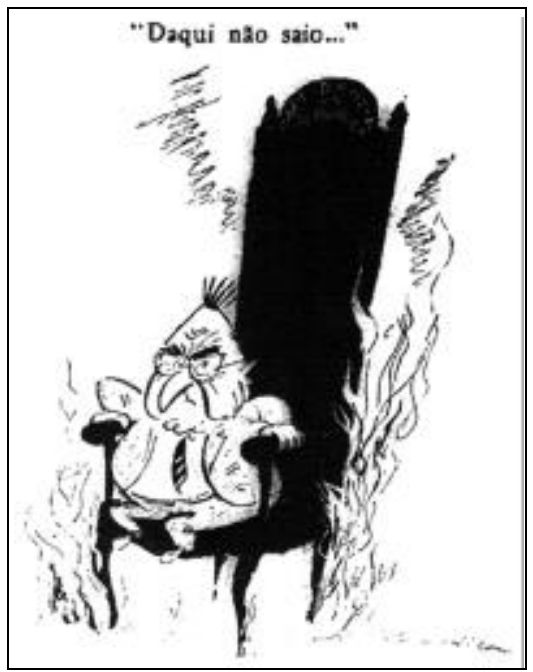

FIG. 2 - Hilde Weber. "Daqui não saio".

Tribuna da Imprensa. Rio de Janeiro, 13/08/1954. 
pante, e toda uma gama de situações políticas que sugere a sua totalidade, levame a crer que se trata de um humorismo "metassemiótico e metatextual", tal como definiu Umberto Eco quando analisou a regra do cômico. Neste caso, aproprio-me da hipótese formulada por Ana Maria Mauad, de ver a imagem - para mim a caricatura - como "um texto icônico que antes de depender de um código é algo que institui um código". E, no contexto da mensagem cômica ou irônica, a imagem, "ao assumir o lugar de um objeto, de um acontecimento ou ainda de um sentimento", segundo a autora, "incorpora funções sígnicas".

Assim, teríamos: o objeto (o trono presidencial), o acontecimento (morrer pela República) e o sentimento (o trágico como possibilidade). Acredito tratarse de uma trilogia existencial imbricada desde 1930, pelo menos, na cultura política getuliana. Há, certamente, muita ironia nestas palavras de Getúlio Vargas, colocadas no seu Diário no dia 20 de novembro de 1930: "Quantas vezes desejei a morte como solução de vida" - escreveu o revolucionário positivista -, "eu, o mais pacífico dos homens, decidido a morrer", pois se dizem que o destino é cego, "deve haver alguém que o guie pela mão". Se, como já foi dito, todo desenvolvimento acaba por parodiar a si mesmo, e uma tal paródia seria a afirmação de que o desenvolvimento sobreviveu à sua própria duração, então a concepção cômica torna-se um momento que ratifica a visualização de uma personalidade, uma tendência e um sentimento. No caso da duração republicana e, em específico, o contexto do getulismo, a ironia está justificada pela história, porque o olho de Clio pode dissecar demônios que habitam territórios e desertos áridos de uma cultura política historicamente produzida. 


\section{IMAGEM DA POLÍTICA}

A permanência da imagem getuliana seria a tônica até mesmo do período presidencial de Eurico Gaspar Dutra. Pode-se dizer que se lembrar do ex-ditador era um recurso fértil na consecução da prática política. Neste caso, como sustentou Jacques Le Goff em seus artigos para as forças conservadoras, sobre as relações entre a história e a memória, utilizar-se da última seria um objetivo e um instrumento de governo. Outra charge do cartunista Théo, publicada na revista Careta em agosto de 1947, mostra vários espaços em que a presença de Dutra é sistematicamente vigiada por Getúlio Vargas. No escritório, na sala de despachos, no clube de golfe, na mesa de refeições, no dormitório e no banheiro, lá está o "republicano-mor" a espreitar e avivar a lembrança de seu sucessor e antecessor (Fig. 3).

Gostaria de destacar as escolhas do caricaturista: as imagens getulianas "perseguem" o governante, principalmente nos espaços privados e íntimos, o que sugere a leitura privatista do devir republicano. A inversão jocosa de que são os

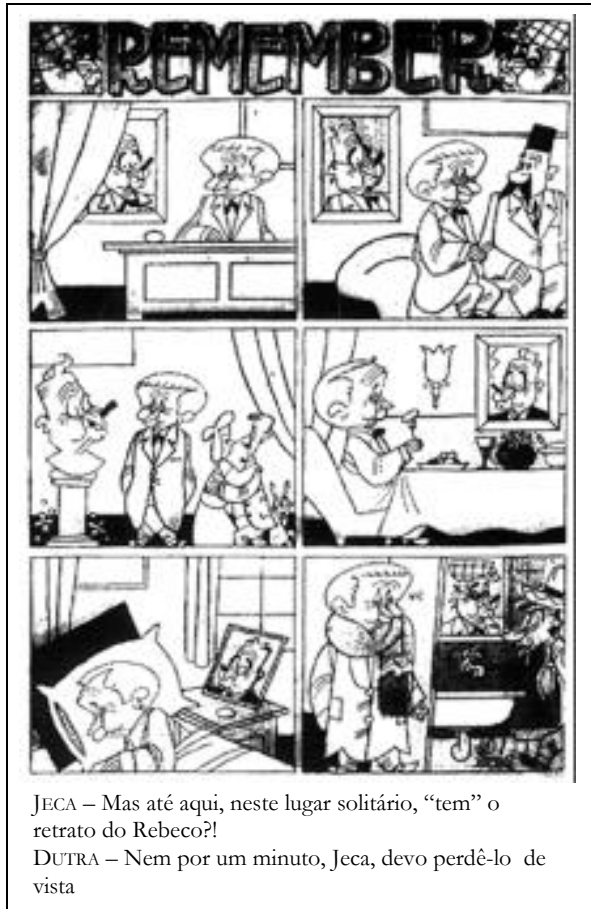

FIG. 3 - Théo. "Remember".

Careta. Rio de Janeiro, 02/08/1947. 
retratos e o busto que observam quem deveria observá-los e a quase ausência dos espaços públicos denotam a "Reprivata", peculiar ao regime político brasileiro. Assim, a caricatura remete a uma constante lembrança imagística da República brasileira, independentemente de suas periodizações: a relação entre o privado e o público, o indivíduo e a comunidade, chegando mesmo à ironização da ciência política através da metáfora de uma "república sem cidadãos". Esta e outras imagens seriam definidoras do gênero característico da comicidade brasileira na República, a paródia, pela qual se desvenda "o solene no familiar, o mecânico no vivo, o público no privado"'.

$\mathrm{O}$ último quadro da caricatura parece-me por demais sugestivo das relações que firmaram a expressão "pai dos pobres": Jeca, alcunha do homem pobre e sem instrução, vê-se refletido no espelho do lavabo de Dutra, na imagem de Getúlio. Então, o homem pergunta ao "friorento" presidente: “- Mas até aqui, neste lugar solitário, ‘tem” o retrato do Rebeco?!” E Dutra responde: “- Nem por um minuto, Jeca, devo perdê-lo de vista...”. A própria familiaridade de tratamento do homem do povo para com Getúlio, o apelido Rebeco, a imagem espelhar de um no outro seria retrabalhada na memória do caricaturista pela jocosidade intimista. $\mathrm{O}$ autor deixa-se levar para um passado quente e recente - quinze anos de República em mãos getulistas -, quando parece ter se afirmado no imaginário 140 popular a figura de Getúlio como o grande guia da República brasileira. Foi o que Angela de Castro Gomes chamou de "a criação do tempo festivo", a partir das comemorações do $1^{\circ}$ de Maio, do aniversário do presidente e da fundação do Estado Novo. O intimismo da última cena sugere, pois, uma aproximação com a ideologia estadonovista, isto é, a impossibilidade de a República pautar-se pelos "instrumentos de representação da democracia liberal"10. Dutra havia sido o escolhido ocasional, cujo tempo presente não era mais do que decepcionante, ao passo que Vargas seria o ungido pela relembrança quase mítica da história vivida e ainda ardente.

A insidiosa pergunta do Jeca ao governante da República indica-nos que a população simples, de uma maneira geral, comunica-se de forma figurada e expressiva, pois, segundo Propp, seu discurso "caracteriza-se por imagens visuais", isto é, a expressividade e o colorido da língua que se dão pela fala (oralidade) em contraposição ao mundo formal e incolor com que se comunica a inteligentsia, principalmente na questão da coisa pública. Para o autor russo, o humorista conseguirá seu objetivo somente quando tiver se "apropriado de todas as particularidades e sutilezas" do discurso popular, rico em comicidade. ${ }^{11}$

Penso que a charge em seis atos, construída pelo intelectual do traço da revista Careta, ao dar comicidade à representação cotidiana dos "figurões" da política, instituiu um desejo latente dos populares: desnudar o poder, bisbilhotá-lo 
na intimidade e, se possível, também tirar-lhe o proveito necessário. Desejos que a circularidade de ordens e hierarquias vinha consagrando nos liames de ações autoritárias, e tecidas pelos que também obedeciam. Como a ação dos agentes policiais que vasculharam a biblioteca do Barão de Itararé, quando um deles, depois de recolher da estante uma coleção de livros de capa vermelha, teria expressado em voz alta, de forma inequívoca, uma imagem incongruente: "Augusto Comte... Esses comunistas arrumam cada nome...”. O policial teria apontado para o mais destacado volume de todos, não por acaso O Capital, de Karl Marx, indagando imediatamente ao Barão de Itararé o significado daquilo. $\mathrm{O}$ "anfitrião" da polícia não teve outra saída: “ - É a minha Bíblia. E fora da Bíblia não há salvação...". Tempos oblíquos e dizeres patéticos que espelham, de certa forma, uma "bagunça totalitária", tentativas de apropriação de conceitos legitimistas e perplexas palavras de ordem: “Abaixo a República! Abaixo a Monarquia! Viva a Dinarquia!"

A visualidade dos conceitos foi instituinte dos vários projetos políticos em torno da República, ora vista como nova, ora acusada de populista. Pode-se dizer que haveria duas invenções, dois modelos de República que se fragmentavam no burburinho da cultura política: ditadura e democracia. E não se pense que ambas fossem diametralmente opostas, pois houvera em pouco tempo, na mesma República, ditadura com democracia social e democracia liberal com estado de sítio. As sensibilidades intelectuais pareciam refletir os ânimos e os espíritos em torno dos conceitos. Érico Veríssimo testemunharia que, em 1945, as coisas políticas e literárias tendiam para uma terrível simplificação: acendia-se uma vela para o Papa e outra para Stálin. O escritor gaúcho achava uma desgraça "quando as pessoas perdem o senso dos matizes". Talvez fosse o caso de lembrar Max Weber que, ao analisar "a política como vocação", disse que, do ponto de vista psicológico, as estruturas políticas são movidas pela satisfação que o homem experimenta por demonstrar a devoção de um crente em favor do êxito da causa de pessoas públicas e não apenas em favor de "abstratas mediocridades contidas num programa". Portanto, o carisma seria uma fé de utilidade política direcionada a uma individualidade excepcional.

A caricatura que foi capa da revista Careta em março de 1946 trabalha a imagem desta dicotomia: “A terra em tal maneira é graciosa..." (Fig. 4), representando a ditadura a partir da máscara de um gordo palhaço, sobressaindo-se da boca o charuto, marca registrada do político Getúlio Vargas. Definia-se, portanto, um espectro da República, cuja imagem horizontal partia do centro - o baixinho do charuto - e se espalhava nos interstícios sociais, a saber, os getulistas, os sindicalistas, os estadonovistas e os críticos da "boa e velha" democracia do "dei- 
xar fazer". Todos estavam na fisionomia bonachona e irresponsável do palhaço, eram os adeptos conscientes e inconscientes da ditadura.

Observe-se a imagem da democracia: de corpo inteiro, a silhueta angelical, com roupas leves adornando o corpo sensual da musa, a sugerir um ideal de República irresistível para o olho que vê. Mais do que isso, a feminina democracia joga graciosamente sementes na terra, para ver frutificar os seus frutos. Assim, não se aponta nenhum espectro, e não são discerníveis os agentes que abraçariam a causa. Creio que a chave interpretativa do foco central da imagem não pode descartar a ansiedade do desejo, aliado ao construto do tempo moral. Assim, a mensagem tem o seu desfecho na intertextualidade, através da voz da musa, que responde às impertinências da ditadura: "Se a semeadura for de cardos, nascerão cardos, mas se semearmos lírios, teremos lírios." Sustento que o embate polifônico entre as representações carnais - ditadura e democracia - pautava-se pela aquiescência, isto é, aquilo que Bakhtin denominou de objeção motivada. Pois, em certo sentido, "o primado pertence justamente à resposta, como princípio ativo: ela cria o terreno favorável à compreensão de maneira dinâmica e interessada. A compreensão amadurece apenas na resposta"13.

Compreensão e resposta que adornavam a gramática republicana com a con-

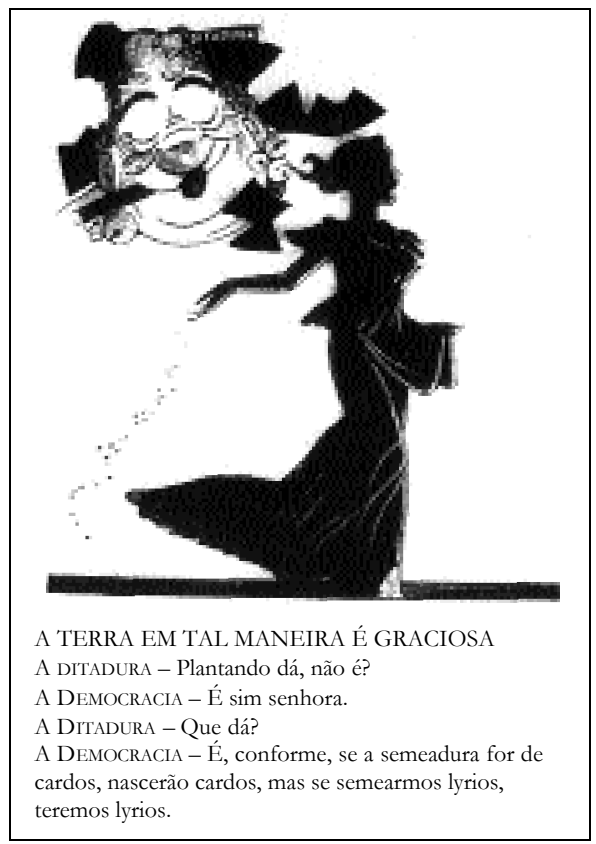

FIG. 4 - "A terra em tal maneira é graciosa". Careta. Rio de Janeiro, 16/03/1946, (capa). 
vicção da vontade: uma República de lírios, capaz de atingir "o máximo de bemestar social com o máximo de liberdade individual" não seria deveras incompatível, quando os republicanos "gostam de ócio e têm um prodigioso senso de humor"? Essas argutas ironias de Érico Veríssimo pareciam sustentar seu ódio a todos os tipos de ditadura, "inclusive os chamados benignos e paternalistas" (acusação ao Estado Novo?). Mas Érico não deixava de ser uma individualidade excepcional que verbalizava uma postura tipicamente liberal e recorrente em boa parte dos intelectuais republicanos. Ora, mais uma vez, a ironia justificaria a história: a ditadura subseqüente, a dos militares, e dos civis, e dos tecnocratas, e dos políticos - "todos democratas" -, legalizou-se, justamente, através da prática discursiva em que ela mesma aparecia como a "mantenedora" das liberdades individuais, ameaçadas pelo riso fácil e escarnecedor da "chanchada" brasileira, a saber, o namoro do "populismo" com o comunismo. Não se deve esquecer o mandamento das Associações Comerciais, publicado no Diário de Notícias em março de 1964: “Armai-vos uns aos outros porque nós já estamos armados.” Em meio a essas trovoadas ideológicas, o espectro de um sistema acusatório, o populismo, tornava-se uma categoria explicativa das idiossincrasias da luta de classes no capitalismo brasileiro.

Assim, a invenção da "redemocratização" como murmúrio das vozes do passado - democratizar novamente, regredir, movimento para trás -, engendrada na cultura política da década de 40, parece ter petrificado a narrativa em torno dos contrários aparentes. A caricatura analisada pretendeu ser o instantâneo de uma polarização que não "desenhava" toda a complexidade do cenário social e político. Talvez seja importante salientar que as dicotomias são, na maioria das vezes, nomeações que calcificam imagens de estranhamento do Outro, o impuro, o malandro, o comunista, o populista, o pelego, o ladrão, e assim por diante. Mas, a meu ver, é a comicidade da imagem, com seus discursos cifrados, que torna possível perscrutar a "profusão de significados que se antagonizam num contexto de ampla transformação". Processo este marcado por descontinuidades e antes questionador da imagem da epifania republicana, isto é, a insistência da "democracia rediviva" em nós, cabendo aos outros a "ação do Amigo da Onça vontade de agressão, ruptura com a ética visível, anúncio do compromisso com prazer e poder como horizontes pessoais" ${ }^{\text {"14. }}$. Teríamos então a entronização de um retorno sem espaço, tempo e origem, senão pela ditadura dos fatos que se encerrariam em si mesmos: 1989, 1946, 1930, 1889 e outros tantos "novecentos". Parafraseando Eco, eu aventaria a seguinte hipótese: uma República que, segundo a tradição intelectualista, nascera bestializada e criada por engano, seria um "cosmos abortado", tendo como principal efeito o tempo sentido, que passa como "uma imitação deformada da eternidade" "15. República essa cara aos produtores do cômico, aos intelectuais do traço, ou, como afirmou Saliba, a "toda 
aquela malta de jornalistas obscuros" e "outros escreventes, não menos desenraizados do que o resto da população" ${ }^{\text {"16 }}$.

\section{VÍCIOS E VIRTUDES}

Sabe-se que as artes, de uma maneira geral, penetram na sensibilidade humana e se expressam nos valores, idéias, memória, observações, olhar, descrições... nelas, embora as percepções estéticas possam ser relevantes, não podem ser tomadas como globalmente definidoras de um sistema de crenças políticas. Na maioria da vezes em que os caricaturistas inventam a sua arte e narram a trama, fazemno pela associação da imago com a grafia. Tal procedimento foi genialmente explorado por J. Carlos (José Carlos de Brito e Cunha), quando satirizou a campanha presidencial que se desenrolava em torno da sucessão de Getúlio, em 1937. A idéia partiu de um mote recorrente na cultura política da República, e deu o próprio título para a charge: "No meio, a virtude", publicada na revista Careta em abril de 1937, quando já se aventava uma nova ordem jurídica.

Trato agora da sua espacialidade: ao fundo, os próceres da República que circulavam nos arranjos políticos com possibilidades de algum sucesso eleitoral. Ao centro deles, o presidente com o seu peculiar charuto, a sorrir e iniciando diálogo com os presentes. Em primeiro plano, observam-se os nomes dos personagens grafados numa suposta descompostura estética. No entanto, na parte central dos nomes, o olhar vê, de forma saliente, a composição vertical de um código que se mostra intencional: Getúlio. E, ao tempo em que o mesmo toma para si todas as atenções, fala e demonstra: “- Sim, haverá 'sucessão', isto é, sucesso grande! O vencedor está entre esses nomes” (Fig. 5).

Segundo informações de Herman Lima, consta que a idéia narrada pelo traço de J. Carlos lhe fora enviada por um leitor da revista, o que demonstra a percepção cômica, por parte da população, quanto à prática política republicana. ${ }^{17} \mathrm{~A}$ circularidade de imagens e dizeres colocaria a trama da sucessão no próprio "habitus social", assim como o "senso de investimento" de seus atores mais privilegiados não deixaria de produzir reviravoltas e renegações que "levam às mais baixas tarefas da polêmica política", segundo a lógica do "mercado de bens simbólicos" (aproprio-me das expressões de Bourdieu): os candidatos, os dizeres retóricos, as silhuetas de homens públicos, as preferências morais e ideológicas, o cheiro de permanência, a costura dos pactos. E a ironia em torno do enredo estaria também presente nas articulações mais íntimas e secretas. Vítor Konder, ao escrever para Osvaldo Aranha, não deixou por menos, embora tivesse sido "traído" pelos fatos: "O presidente, em cujo crânio a mosca azul do 'Fico' deixou de zumbir, persegue a miragem do 'candidato único', cogitação romântica que evidencia o propósito de nada resolver." ${ }^{18}$ 


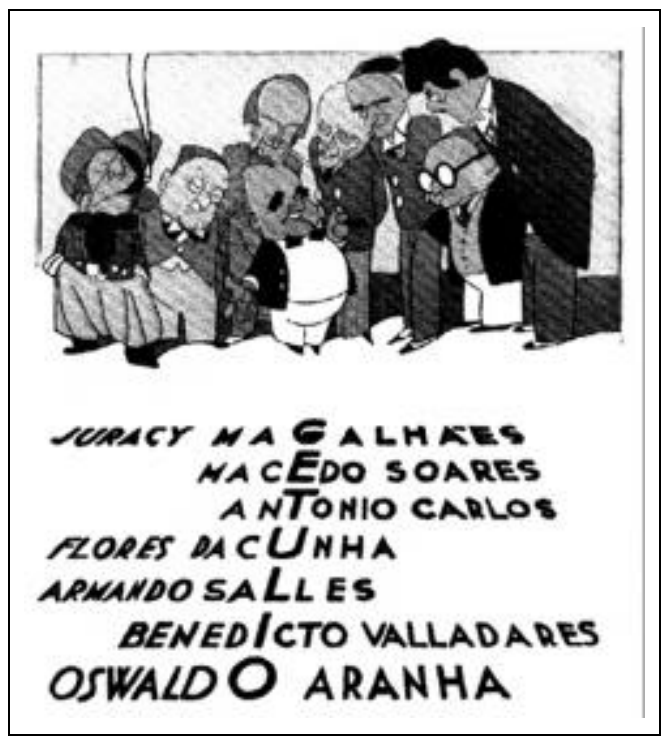

FIG. 5 - J. Carlos. "No meio, a virtude".

Careta. Rio de Janeiro, 24/04/1937.

O mais impressionante parece ser o caráter premonitório da imagem que antecipa em seis meses os acontecimentos da novembrada de 37 e, de certa forma, constituiu-se na própria ironia que selaria a construção mítica das virtudes do "bom" republicano: a magia política, a intuição do certo, a profecia e a predestinação, o espírito demiurgo de racionalidade, planificação e previsão. A centralidade e o amálgama entre nome e imagem seriam o construto do mito Vargas, o homo magus, o homo faber. Talvez fosse o caso de se dizer: "o homem ficante", o presente que não se tornava passado. Foi mais ou menos esta a sensibilidade de José Américo de Almeida, no primeiro comício do lançamento de sua candidatura que, como a de Armando Sales de Oliveira, seriam preteridas em busca do Tertius que se desenhava: "o dia de amanhã é nosso pior dia: não chega nunca" $"$.

A idéia explorada pela caricatura - a virtude no meio e mediada pela política - parecia recorrente entre os intelectuais refratários aos projetos radicais de Estado e de sociedade. Segundo Angela de Castro Gomes, a noção de pacto nos anos 30 incidia sobre o nível dos atores coletivos, e envolvia intelectuais e aparelho de Estado com a premissa de terminar o "divórcio entre os trabalhadores brasileiros e o Estado". Neste caso, a ordem política privilegiaria o "consenso", cabendo aos intelectuais a construção do amálgama cultural para afastar o radicalismo político e polir o amontoado de nomes e discursos retóricos que obscureciam a "virtude". 
Assim, os intelectuais seriam "atores e criadores por definição de bens simbólicos que alimentam a própria mecânica de funcionamento do poder"20.

Todavia, como as mensagens não possuem receptores homogêneos, a sátira também se apropriava de certas imagens pouco edificantes. Foi o caso da formulação de uma jovem de quinze anos, Ady Torelly, que de São Paulo escrevera ao pai, Aparício Torelly, no Rio de Janeiro, sobre nomes da política e o contexto do Estado Novo. A hilaridade da carta ao conectar os figurões da política internacional aos fios de cabelo do pai, e a ironia ao getulismo parecem ser sugestões à queda dos regimes: "O frio aqui é de rachar até a raiz dos cabelos. Ah! E por falar em cabelo, como vão os seus? O Hitler; o Mussolini? Já caíram? Acho melhor não batizar um deles de Getúlio porque se não der resultado, cai todo o cabelo e só fica um fio, que é o tal." ${ }^{21}$ Certamente o pai da jovem missivista, que era "barão", satirista e comunista, deve ter rido muito da facécia verbal da filha, do seu estilo e linguagem, a questionar o consenso em torno de uma simbologia de poder. $\mathrm{O}$ gênero cômico e livre da carta, grafando o riso, demonstra que, numa acepção semiótica, o político e o privado foram atravessados pelas tramas e intrigas do simbólico que, conforme sempre acontece, segundo Umberto Eco, demonstra-se produtor de realidade. E se Getúlio Vargas representou simbolicamente a ditadura, rompendo com "o passado político brasileiro", de cunho "democrático" segundo os liberais, especialmente os paulistas, haveria ainda assim uma notável permanência na cultura política da República: enormes dificuldades para tolerar o dissenso político, a alteridade social e a complexidade cultural. ${ }^{22}$

A imagem da República está associada à espacialidade do Palácio do Catete, centro de emanação da ordem e visualização do poder. Uma das charges mais difundidas que retrataram a política getuliana foi traçada por J. Carlos para a revista Careta, em janeiro de1937, com um efeito satírico devastador: em primeiro plano aparecem bananeiras com portentosos cachos da fruta tropical; mais ao centro, no meio da rua, vê-se o "baixinho" Getúlio e seu inconfundível charuto, com um cesto cheio de cascas de bananas e outras tantas já espalhadas pela via pública (calçada e rua); ao fundo ergue-se pomposamente o Palácio do Catete, onde sobressaem o portão principal, as sacadas e as águias no alto da fachada preparando-se para alçar vôo; no oitão do palácio, encostado numa de suas colunas, aparece o Jeca, o homem do povo, de chapéu, com as pernas cruzadas fazendo o "quatro", e observando a cena com um leve sorriso. A frase de Getúlio parece ser dirigida ao quase invisível personagem e a todos: "- Para que cerca de arame farpado? Bastam as habituais cascas de bananas...” (Fig. 6).

Herman Lima, no seu estudo clássico sobre a caricatura no Brasil, considerou esta charge de J. Carlos como "uma de suas sátiras mais extraordinárias de todos os tempos", pelo "sorriso malicioso de sempre" do presidente e pela maneira do diminuto Jeca, que "magina" a cena interrogativamente. A centralidade 
do "Palácio das Águias", entre a Rua do Catete e a antiga Rua do Príncipe, cuidadosamente vigiado pelas derrapantes cascas, sugere a exploração de uma idéia corrente dos regimes sul-americanos: República de Bananas. Assim vista e de igual maneira negada, a política republicana estaria historicamente ligada à imagem do Catete como lugar e espaço do poder.

A frase getuliana parece-me também inigualável, no que tange à arte da política: na cerca, os arames são entrepostos definitivos que delimitam fronteiras e espaços e, de certa forma, fazem da centralidade do poder uma fortaleza inacessível ou estrategicamente guardada por artefatos repressivos. Já o "deslize", através das cascas de bananas, simbolizaria a "habitual" política, com seus conchavos, facções, interesses, articulações, ascensões e quedas. Enfim, "preparar o terreno", coagir para tentar evitar a coerção e o peculiar monopólio da violência. Embora tal prática getuliana seja identificada como maquiavélica ${ }^{23}$, reputo-a mais próxima da "ciência civil" hobbesiana: "Os pensamentos secretos de cada homem percorrem todas as coisas, sagradas ou profanas, limpas ou obscenas, sérias ou frívolas, sem vergonha ou censura. Coisa que o discurso verbal não pode fazer, limitado pela aprovação do juízo ao momento, ao lugar e à pessoa." Ora, "Ter servidores é poder; e ter amigos é poder", ponderou o teórico da "ciência

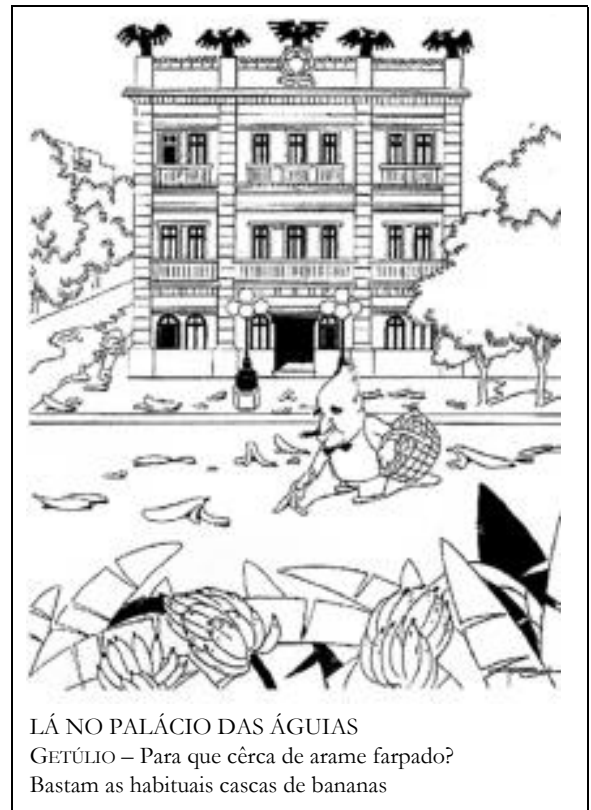

FIG. 6 - "Lá no Palácio das Águias". Careta. Rio de Janeiro, 30/01/1937. 
civil plenamente demonstrativa" ${ }^{24}$. Note-se que a imagem getuliana proposta pelo caricaturista procura descobrir os desígnios do presidente através de suas ações, "coisa que o discurso verbal", com muita freqüência, transformava em virtude e necessidade pelas vestes da prudência e da arte dos pactos, circunstanciais quando de natureza política, duradouros se evoluíssem para a órbita relacional. "Éramos amigos e, eventualmente, cúmplices", lembraria Samuel Wainer em suas Memórias de um Repórter, que se tornara um getulista especial, enquanto "Getúlio Vargas sempre demonstrou enorme prazer pelo fato de ser o número um da República." Neste caso, a dimensão interativa dos agentes pactuantes passa por escolhas e definições que se refazem na lógica de ganhos práticos e simbólicos, ou seja, "se amigos dão-se presentes", não é difícil sustentar que "presentes fazem amigos" 25 .

A magistral e satírica imagem da "República no Catete", de J. Carlos, permite sustentar a hipótese de que o caricaturista arvorou-se em cientista "da virtude e do vício", pois ele mesmo utilizou os elementos da política: a necessidade da eloqüência, a invocação dos lugares-comuns, a ampliação dos argumentos e a persuasão como meio de inculcar no "leitor" o riso malicioso. Então, seria possível argumentar que a charge, como a arte da retórica, "deprecia a virtude e desculpa o vício", tal como observou Skinner a respeito da ironia hobbesiana. E, assim, escarnece-se a política na acepção que tem a ver com "quem manda, por que manda, como manda", uma vez que "mandar é decidir, é conseguir aquiescência, apoio ou até submissão". Para o sátiro das coisas públicas valeria, mais do que a indagação sistemática, a irônica exclamação carregada de sentidos: "Que coisa é a Política!'26

\section{(Des)Cobrir a RepÚblica}

A "descoberta” de que a tradição da República haveria de ser resgatada pelos seus "grandes homens" não escapou ao cômico das situações calcadas na cultura do estranhamento. Ao se referir ao método de construção de "autobiografias dirigidas", o sociólogo Gilberto Freyre relata a atitude de Vargas diante de sua metodologia: "Getúlio Vargas, solicitado por nós, em 1940, em Petrópolis, a responder ao nosso inquérito, observou maliciosamente, depois de o ler, a princípio com um meio-sorriso, de certa altura em diante, sério e concentrado: 'Este inquérito descobre qualquer um. E eu não sou homem que se descubra, mas que deve ser descoberto." Freyre não perderia a oportunidade para devolver a ironia e, no próprio texto que relembrou o episódio, deixaria a descoberto o homem, ao afirmar que o Trabalhismo brasileiro nasceria de raízes positivistas: "Positivistas naqueles pontos em que seu programa refletiria idéias, sentimentos ou sugestões de Getúlio Vargas. Porque Vargas seria brasileiro até o fim da vida, marcado 
por sua formação positivista. Um vivo fortemente influenciado por um morto: Júlio de Castilhos. Um cúmplice de agitadores progressistas que nunca deixaria de ser um aliado secreto dos brasileiros preocupados em resguardar de perturbações estéreis a ordem nacional." ${ }^{27} \mathrm{O}$ que parece ser importante no depoimento de Gilberto Freyre é que sua memória procura fixar imagens da construção republicana a partir de idéias e homens, estabelecendo a dispersão do sujeito na duração temporal - Vargas na República - e optando pelo recuo incessante da gênese - a tradição positivista de certos homens republicanos.

A caricatura de (Alfredo) Storni, que descrevo a seguir, sobre o advento da "República Nova", publicada na revista Careta em dezembro de 1930, parece se aproximar das questões relembradas pelo sociólogo pernambucano. A cena desenrola-se na enfermaria de um hospital: na parede branca, um quadro mostra um revolucionário em movimento, o nome de João Pessoa (dimensão trágica de 30) e a data evocada dos batalhões e clubes revolucionários (três de outubro); em primeiro plano, dois "médicos" estabelecem diagnósticos e posologias para a República doente e desfigurada , prostrada no leito de uma cama mais ao fundo; Osvaldo Aranha, de avental branco, demonstra os artefatos propícios para anestesia e conseqüente operação cirúrgica; porém, mais próximo da paciente, vê-se o homeopata Getúlio Vargas enfatizar o seu método curativo; então, a República que está representada pela mulher deitada, queixa-se para o leitor: “- No princípio prometeram-me com espalhafato a intervenção cirúrgica, mas no fim foi aquela agüinha...” (Fig. 7).

Acredito que o caricaturista preferiu demonstrar a jocosidade a partir das inversões: afigura-se com a Revolução de 30 a República Nova, mas ela é demonstrada como velha e enferma, e sua fala torna-se cética quanto ao tratamento que estava recebendo. O "revolucionário" é retratado como médico homeopata, aquele que adota a terapêutica com doses ínfimas, sem causar qualquer traumatismo estrutural ao paciente. Alguns detalhes da cena ganham importância nesta abordagem: a cartilha da homeopatia que Vargas porta na mão direita, ao mesmo tempo que levanta o frasco com a esquerda, sugere o próprio mote do tratamento, de que "os semelhantes curam-se pelos semelhantes". Assim, a República convalescente somente se recuperaria a partir de medidas homeopáticas, à sua imagem e semelhança, isto é, para a ordem e dentro dela. Outro elemento destacável é a alegoria feminina da República que, no leito hospitalar, está à mercê dos políticos do regime. Com efeito, trata-se de uma alegoria recorrente dos caricaturistas na duração republicana, talvez pela seqüência de eventos refundadores do mesmo, a paródia da República que, não sendo jovem e bela, também não era desejável. Assim, o desejo conquistado inverte-se no mal necessário de uma suposta velhice da República constantemente maquiada pelos homens 
que a usufruem. Refiro-me, claro, à inversão bergsoniana, na qual uma cena cômica pode fazer "com que a situação volte para trás e com que os papéis se invertam" na dimensão psicológica de um "mundo às avessas".

A inversão das imagens torna-se patente se compararmos o traço de Storni com uma fotografia do último dia de outubro, em que aparecem numa sacada do Palácio do Catete os dois "médicos" da República: Osvaldo Aranha, de terno e sonolento, assiste ao lado de Getúlio Vargas, com roupas militares, às manifestações populares pela revolução de outubro que chegara triunfante à capital da República. ${ }^{28}$ Neste caso, a "reflexão possível" seria atentar para o fato de que a República está na totalidade do ato fotográfico, nos líderes, na multidão, no espaço de poder e suas hierarquias (a sacada e a rua), e no tempo presente do fazer-se, isto é, o triunfo da celebração de um advento, a revolução, não importa que tipo de terapia lhe fosse administrada. Entretanto, não defendo nem sugiro que a imagem fotográfica seja mais verdadeira que a caricatura, ao contrário, acredito que ambas são artefatos e significantes de cultura, no caso de cultura política, uma vez que, como qualquer outra fonte que narra fatos e versões, toda imagem é produzida historicamente. E em termos da inversão humorística, talvez haja semelhança com a textualidade da memória quando "inventa", a respeito de seu tempo e dos outros, imagens verossímeis. Pois, como afirma Bakhtin ao definir o contexto rabelaisiano, toda obra que registra "saiu do próprio centro da vida da época, na qual o autor era participante ativo ou uma testemunha interessada".

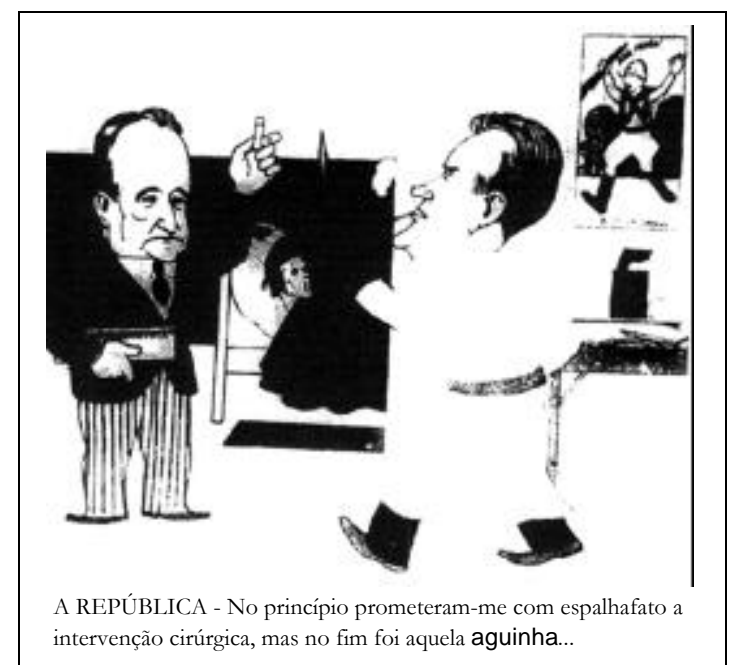

FIG. 7 - Storni. "Tinha de ser...".

Careta. Rio de Janeiro, 06/12/1930. 


\section{APOGEUS E QUEDAS}

As reflexões retrospectivas deste artigo em torno da historicidade republicana marcada pelo getulismo tentaram demonstrar que o universo da política não escapa ao patético e ao cômico, elementos que os intelectuais do traço e os memorialistas representaram em discursos (visuais e textuais). Em 24 de agosto de 1954, o suicídio e a carta-testamento transbordaram o "cálice da aliança" que o povo, na história, viveu, chorou e vingou; na véspera e semanas anteriores, tradições antigetulistas fortalecidas pela "opinião publicada" clamavam: "Morra Getúlio!’”29 Em 1950, o carisma construído, a volta em triunfo, porque houvera algo de terrível no interregno dutrista (repressão aos sindicatos e trabalhadores), daí a perplexidade dos articulistas, letrados e "racionais" da revista Anhembi, São Paulo, de que meio milhão de "espíritos recalcados e justamente ressentidos" havia descido os morros para "votar na única esperança que lhes restava", que, segundo a expressão desdenhosa, era o "messias-charlatão". Francisco Weffort, em estudo referencial sobre O Populismo na Política Brasileira, não percebeu que se tratava de um poderoso sistema de acusações e preconceitos intelectualistas, e definiria todo esse embate ideológico como apenas sendo uma "sensibilidade liberal tradicional". A ironia da história em parte daria razão aos editorialistas da publicação: o Messias não é o que promete, mas aquele que denuncia o presente e anuncia o tempo novo, a parúsia da carta-testamento. O charlatão, que apregoa virtudes exageradas aos remédios que oferece ao público, charla da vida e glosa da morte, numa palavra, suicida-se. Neste caso, aventaria a hipótese do horror cômico de um "riso exterminador" que rondou a República até 1964: uma "excepcional animação" e euforia nacionalista, junto a um "sentido agudo de desastre e da catástrofe iminente" 30 .

Em 1945, entre o queremismo e a deposição, a força dos liberais e dos racionalistas em torno do regime parlamentar e representativo, desde que os "jacobinos" não lhe perturbassem a Ordem - uma categoria metafísica da República -, o getulismo seria adubado pela memória mítica. Em 1937, o ditador está no governo e se faz Estado Novo, sendo relembrado por uma charge publicada na revista Careta, em outubro de 1955: Jeca, esse republicano sem República, aos ouvir as preleções de Gustavo Capanema, pergunta-lhe: “- Você contra a ditadura, seu Capanema? E 1937?” O ex-ministro da Educação do Estado Novo então responde: " - Em 37 não houve ditadura, por falta de ditador. O golpe era continuísmo". Finalmente, em 1930, o "pai dos pobres" não era senão um oligarca da tradição positivista do Brasil meridional, que perdera um típico pleito liberal, cuja "reviravolta da revolução" determinaria as primeiras derrotas dos republicanos vestidos de conselheiros e bacharéis. Dir-se-ia, quem sabe, o riso sardônico para o ritual antropofágico da República constantemente envelhecida, 
cuja duração parece ter sido profetizada num "vale de emoções, de apogeus e de quedas de Ícaro" pela lancinante sátira modernista de Oswald de Andrade, na narrativa de Memórias Sentimentais de João Miramar: "Nessas intermitências de progresso e regresso, círculos de princípios que formam a base de novas babéis, novas confusões de línguas e novos rebanhos voltando a velhos apriscos, só uma lição nos assoberba, a lição severa da História!"

\section{NOTAS}

${ }^{1}$ BOURDIEU, Pierre. As Regras da Arte. São Paulo: Cia. das Letras, 1996, pp. 362-363.

${ }^{2}$ RICOUER, Paul. Tempo e Narrativa. Vol. III. Campinas: Papirus, 1997, p. 124. Paul Veyne postularia a retrodicção como síntese a partir de três níveis: documentos, crítica e erudição. Portanto, “a história de uma época determinada se reconstitui por colocações em série, por idas e vindas entre os documentos e a retrodicção, e os 'fatos' históricos que são, aparentemente, mais consistentes são, na realidade, conclusões que compreendem uma proporção considerável de retrodicção". Cf. VEYNE, Paul. Como se escreve a história. 3. ${ }^{a}$ ed. Brasília: Editora Universidade de Brasília, 1995, pp. 7678.

${ }^{3}$ VERÍSSIMO, Érico. Breve História da Literatura Brasileira. São Paulo, Globo, 1997, p. 137. O próprio presidente escreveria em seu diário sobre a conspiração, inicialmente marcada para a data máxima da República. Getúlio Vargas assim justifica os fatos, ocorridos entre os dias 7 e 15 de novembro: "Não é mais possível recuar. Estamos em franca articulação para um golpe de Estado, outorgando uma nova Constituição e dissolvendo o legislativo. (...) Em vista disso [intriga e divisão dos militares], era preciso precipitar o movimento, aproveitando a surpresa. E assim se fez. Mandei chamar em seguida o chefe de Polícia e o ministro da Justiça. Com este e o ministro da Guerra, combinamos todas as medidas. (...) No dia 15, inaugurou-se, com grande assistência e entusiasmo, o monumento a Deodoro... Recebi calorosas demonstrações populares de uma verdadeira multidão." VARGAS, Getúlio. Diário. Vol. II (1937-1942). São Paulo: Siciliano; Rio de Janeiro, Fundação Getúlio Vargas, 1995, pp. 82-84. Acredito que o testemunho acima citado narra uma "experiência temporal" (os "agoras" do presente) que, a rigor, seria a "história feita e padecida pelos homens". Decerto, haveria na ironia de Érico Veríssimo a "refiguração do tempo pela narrativa". Ver RICOUER, Paul. Tempo e Narrativa. op. cit., pp. 7-13.

${ }^{4}$ TORELLY, Aparício (Barão de Itararé). "República dos Estados Unidos do Brasil.” In Almanhaque: Almanaque de A Manha. Rio de Janeiro, 1949, p. 23. Com o tempo, a sentença de Torelly passou a ser resumida simplesmente como "O Estado Novo é o estado a que chegamos." Outra ironia que ganharia poder de síntese, numa alusão ao regime e aos militares, seria esta: "O Brasil é uma república 'generalizada'.” Ver Máximas e Mínimas do Barão de Itararé. (Seleção e Organização de Afonso Félix de Sousa). Rio de Janeiro: Record, 1985, pp. 67, 74.

${ }^{5}$ Ao reclamar providências do Estado Novo na doação de terrenos à futura Universidade Católica, o padre Leonel Franca dirigiu-se ao ministro da Educação, Gustavo Capanema, em 19 de dezembro de 1942, endossando uma atitude de governo pragmática: “O que se prevê faz-se a tempo e a hora, o que se faz a tempo e a hora dá impressão de ordem, de segurança e de energia. Sob a aparência de uma expressão quase trivial, Goethe anunciou uma grande verdade para o homem de ação: 'O que hoje não se faz, amanhã feito não está'." Ver a "Correspondência Selecionada de Gustavo Capanema." In SCHWARTZMAN, Simon, BOMENY, Helena Maria B. e COSTA, Vanda Maria R. Tempos de Capanema. Rio de Janeiro: Paz e Terra; São Paulo: EDUSP, 1984, pp. 307-308.

${ }^{6}$ CORRÊA, Villas-Bôas. "Eu vi.” In GOMES, Angela de Castro (org.). Vargas e a Crise dos Anos 
50. Rio de Janeiro: Relume-Dumará, 1994, p. 16; RODRIGUES, Nelson. A menina sem estrela. Memórias. São Paulo: Cia. das Letras, 1993, pp. 72-73. Outro jornalista, Samuel Wainer, proprietário do jornal Última Hora e pró-Getúlio, lembraria do drama da República, naquele agosto: "Fui para o jornal, mandei buscar no arquivo uma velha foto de Getúlio com as mãos sujas de petróleo - uma foto célebre - e redigi a manchete que explodiria nas bancas do dia seguinte: GETÚLIO AO POVO: SÓ MORTO SAIREI DO CATETE. A edição esgotou-se em poucos minutos. Rodamos outra, que também não demorou a esgotar-se, rodamos mais uma, e assim seria ao longo de todo aquele dramático 23 de agosto." O memorialista diz ter ficado entrincheirado na redação dia e noite e, às duas horas da madrugada do dia 24 , tomou o seguinte cuidado: "Tratei de redigir manchetes que servissem como opções. Uma delas: GOLPE. Outra: RENÚNCIA. OUTRA: DEPOSIÇÃO. Eu precisava pensar em todas as hipóteses. (...) Às 8:25, ouviu-se um estampido no Catete. Dois minutos depois, Luís Costa chamou-me ao telefone. Aos prantos, entre soluços, meu bravo repórter informou: - O presidente acaba de dar um tiro no coração". Foi então que a tragédia tornou-se pública e ganhou as ruas da República dilacerada: "As emissoras de rádio transmitiam incessantemente a notícia, e um clima de absoluta comoção se espraiava pelo país. Na oficina, encontrei operários chorando, outros desmaiados. Lembrei-me, então, de que a página com a manchete publicada na véspera - SÓ MORTO SAIREI DO CATETE - continuava composta em chumbo. (...) Aquela histórica primeira página, contudo, permanecia intacta, e tive a idéia de republicá-la exatamente como saíra na véspera, mudando apenas alguns detalhes. Numa linha no alto da página escrevi: 'Ele cumpriu a promessa.' Abaixo da frase em que Getúlio prevenia que não o tirariam vivo do palácio, descrevi o suicídio do presidente da República.” WAINER, Samuel. Minha Razão de Viver: memórias de um repórter. Rio de Janeiro: Record, 1987, pp. 203-205.

${ }^{7}$ Ver FERREIRA, Jorge. "O carnaval da tristeza: os motins urbanos do 24 de agosto". In GOMES, Angela de Castro. (org.). Op. cit., pp. 61-96.

${ }^{8}$ MAUAD, Ana Maria. “Através da Imagem: Fotografia e História - Interfaces.” Tempo. vol. 1. nº 2. Rio de Janeiro, Depto. de História, UFF, Dezembro, 1996, p. 93.

${ }^{9}$ Ver CARVALHO, José Murilo de. Pontos e Bordados: escritos de história e política. Belo Horizonte: Editora UFMG, 1998, pp. 83-106; SALIBA, Elias Tomé. “A Dimensão Cômica da Vida Privada na República.” In História da Vida Privada no Brasil. Vol. 3 (República: da Belle Époque à Era do Rádio). São Paulo: Cia. das Letras, 1998, pp. 289-365. Tratar-se-ia, a meu ver, de uma cidadania relacional, pragmática, cujos elos mediadores seriam, antes de mais nada, as pessoas, e não exatamente as instituições. Pelo menos, um depoimento me parece elucidativo das relações e adesões ao getulismo. Não resta dúvida de que a memória de um republicano com posição privilegiada, como a de Samuel Wainer, forçou um "cogito" satírico: "Eu era o amigo do Homem, que era o amigo do povo. Logo, eu era amigo do povo, que tinha, portanto, de comprar meus jornais. Da mesma forma, eu era amigo do Homem, que era amigo dos industriais progressistas. Logo, eu era amigo dos industriais progressistas, que tinham, portanto, de enunciar em meus jornais". WAINER, Samuel. op. cit., p. 171.

${ }^{10}$ GOMES, Angela de Castro. A Invenção do Trabalhismo. 2. ${ }^{\mathrm{a}}$ ed. Rio de Janeiro: Relume-Dumará, 1994, pp. 200-210. Sobre as "ambigüidades discursivas" da política trabalhista e a data dos trabalhadores, ver LIMA, Maria Emília A. T. A Construção Discursiva do Povo Brasileiro: os discursos de 1. ${ }^{\circ}$ de Maio de Getúlio Vargas. Campinas: Editora da Unicamp,1990.

${ }^{11}$ PROPP, Vladímir. Comicidade e Riso. São Paulo: Ática, 1992, p. 133. Creio que a comicidade pode estar presente, de forma velada, latente ou explícita, no conjunto dos discursos visual, oral e escrito. Nesse sentido, não descartaria a tese de Bakhtin, apesar de sua generalidade: "A cultura do riso e do cinismo cômico pode, menos que qualquer outra, ser qualificada de cândida e não tem em absoluto necessidade da nossa condescendência. Ela exige de nós, pelo contrário, um estudo e uma 
compreensão atentos." BAKHTIN, Mikhail. A Cultura Popular na Idade Média e no Renascimento: o contexto de François Rabelais. São Paulo: Hucitec; Brasília: Editora UnB, 1993, p. 131. Sobre a "cultura da comunicação," ver BURKE, Peter. A Arte da Conversação. São Paulo: Unesp, 1995; CHARTIER, Roger. A História Cultural: entre as práticas e as representações. Lisboa: Difel; Rio de Janeiro, Bertrand Brasil, 1990.

12"A Bagunça Totalitária." In: FIGUEIREDO, Cláudio. As duas vidas de Aparício Torelly, o Barão de Itararé. Rio de Janeiro: Record, 1988, pp. 77-133.

${ }^{13}$ BAKHTIN, Mikhail. Questões de Literatura e de Estética. São Paulo: Unesp/Hucitec, 1993, p. 90 .

${ }^{14}$ Ver MAUAD, Ana M. \& GRINBERG, Lúcia. "O século faz cinqüenta anos: fotografia e cultura política em 1950.” In Revista Brasileira de História. vol. 14. n. ${ }^{\circ} 27$. São Paulo, Anpuh, pp. 129148; 1994; SILVA, Marcos Antonio da. Prazer e Poder do Amigo da Onça: 1943-1962. Rio de Janeiro, Paz e Terra, 1989, pp. 34, 216. Imagem expressiva seria a caricatura de Getúlio Vargas com o Amigo da Onça, fig. 8, p. 236.

${ }^{15}$ ECO, Umberto. “Interpretação e História.” In Interpretação e Superinterpretação. São Paulo: Martins Fontes, 1997, p. 42.

${ }^{16}$ SALIBA, Elias Tomé. Op. cit., p. 338. Seria importante ressaltar que a República, independentemente de seus períodos mais ou menos autoritários, sempre se constituiu numa arena de batalha por imagens cândidas de uma suposta sociedade que se pautaria pela ordem e pelo progresso. Desta forma, assumo a reflexão de Bourdieu quando afirma que "as tomadas de posição intelectuais e artísticas constituem, via de regra, estratégias inconscientes ou semiconscientes em meio a um jogo cujo alvo é a conquista da legitimidade cultural, ou melhor, do monopólio da produção, da reprodução e da manipulação legítimas dos bens simbólicos e do poder correlato de violência simbólica legítima." Daí o meu esforço em não cair nos braços da teoria sociológica que fez do getulismo verso e reverso da categoria "populismo", esse polvo de sete cabeças e manipulador de consciências intelectuais e, especialmente, operárias. BOURDIEU, Pierre. A Economia das Trocas Simbólicas. 5. ${ }^{a}$ ed. (Introdução, organização e seleção de Sergio Miceli). São Paulo: Perspectiva, 1998, p. 169.

${ }^{17}$ LIMA, Herman. História da Caricatura no Brasil. Vol. 1. Rio de Janeiro: José Olympio Editora, 1963, pp. 345, 352.

${ }^{18} \mathrm{O}$ missivista não poupa ironias à situação vigente: “Anuncia-se o 'regime da madeira'. Mas, meu caro, o caminho da violência não permite recuos sem arranhões à dignidade do poder... O presidente aferrado ao humano e compreensível propósito de não se diminuir em prestígio - procura ganhar tempo, deixando para tomar a 'decisão extrema' na 'hora extrema'!" Ver "Carta de Vítor Konder a Osvaldo Aranha, tratando da sucessão presidencial, Rio de Janeiro, 01/05/1937." In CAMARGO, Aspásia, RAPOSO, Eduardo, FLAKSMAN, Sergio. O Nordeste e a Política: diálogo com José Américo de Almeida. Rio de Janeiro: Nova Fronteira, 1984, Apêndice 14, pp. 507-508.

${ }^{19}$ Mas haveria no próprio candidato a velha e sempre renovada estratégia salvacionista: "Prometo nutrir, vestir, curar". Citado em CAMARGO, Aspásia [et al.]. O golpe silencioso. Rio de Janeiro: Rio Fundo, 1989, pp. 183. Sobre o mito Vargas, ver VELOSO, Mônica Pimenta. "Cultura e Poder Político: uma configuração do campo intelectual." In Estado Novo: ideologia e poder. Rio de Janeiro: Zahar Editores, 1982, pp. 71-108.

${ }^{20}$ GOMES, Angela de Castro. História e historiadores: a política cultural do Estado Novo. Rio de Janeiro: Fundação Getúlio Vargas, 1996, pp. 135-137.

${ }^{21}$ Carta de Ady Torelly a Aparício Torelly. São Paulo, 15/10/1940. Citada em FIGUEIREDO, Cláudio. Op. cit., p. 137. Uma das satíricas frases que Aparício Tollery colocou na boca de seu persona- 
gem “G. Túlio Vargas” foi esta: “1930: Vamos deixar como está para ver como fica. 1945: Vamos deixar como está para ver como fico.” Máximas e Mínimas do Barão de Itararé. op. cit., p. 71.

${ }^{22}$ Ver FERREIRA, Jorge. Trabalhadores do Brasil: o imaginário popular - 1930-45. Rio de Janeiro: Fundação Getúlio Vargas, 1997. Sobre os esforços dos “estadonovistas” para expurgar “o conceito de democracia das ficções liberais", bem como suas críticas ao formalismo político ou à "questão da representação", ver GOMES, Angela de Castro. "O Redescobrimento do Brasil." In Estado Novo: ideologia e poder. op. cit., pp. 109-150; e, da mesma autora, A Invenção do Trabalhismo. 2. ${ }^{a}$ ed. Rio de Janeiro: Relume-Dumará, 1994, pp. 173-194. O próprio Getúlio, mesmo ante o avanço do fascismo durante a guerra, não pouparia críticas ao conteúdo liberal das democracias ocidentais: "O povo, por instinto, teme a vitória alemã; os germanófilos exaltam-se. Mas o que ressalta evidente é a imprevidência das chamadas democracias liberais”. VARGAS, Getúlio. Op. cit., p. 313.

${ }^{23}$ Por exemplo, CAMARGO, Aspásia. "Carisma e personalidade política: Vargas da conciliação ao Maquiavelismo.” In Ciências Sociais Hoje. No 3. São Paulo, Anpocs, pp. 308-340, 1985. A autora pretendeu analisar quatro dimensões da "personalidade política" de Vargas, elegendo-as nesta ordem: "o conciliador, o árbitro, o caudilho e o maquiavélico" (op. cit., p. 315). Apesar de seu complexo arsenal metodológico, o estudo parece ter apenas reforçado o estereótipo do "populista diabólico", talvez mais contundente em HENRIQUES, Afonso. Vargas, o maquiavélico. Rio de Janeiro: Record, 1966.

${ }^{24}$ HOBBES, Thomas. Leviatã ou Matéria, Forma e Poder de um Estado Eclesiástico e Civil. São Paulo: Abril Cultural (Os Pensadores), 1983, pp. 44-59. Baseio-me em Skinner para sustentar a hipótese de que a "estratégia política" de Vargas se aproximaria do "procedimento teórico" de Hobbes, especialmente quando se destacam os tropos da retórica e da ironia. Skinner afirma que, para Hobbes, sua "preocupação dominante, como ele nos lembra reiteradamente, é garantir a paz. O que ele demonstrou, segundo afirma, é que a melhor maneira de se servir à causa da paz é através de um compromisso permanente com a justiça e com toda a gama das demais virtudes sociais. (...) ele é, em essência, um teórico das virtudes, cuja ciência civil centra-se na afirmação de que evitar os vícios e manter as virtudes sociais é indispensável à preservação da paz". Ver SKINNER, Quentin. Razão e Retórica na Filosofia de Hobbes. (Trad. de Vera Ribeiro). São Paulo: Editora Unesp, 1999, pp. $17-37$.

${ }^{25}$ GOMES, Angela de Castro. op. cit., pp. 159-172; ver também BOBBIO, Norberto. "Política." In: Dicionário de Política. Vol. 2, 8ª ed. Brasília: Editora UnB, 1995, pp. 954-962; e sobre política e representações, ver discussões recentes em ANDRADE, Maria Antônia Alonso de. Cultura Política, Identidade e Representações Sociais. Recife: Fundação Joaquim Nabuco/Ed. Massangana, 1999.

${ }^{26}$ RIBEIRO, João Ubaldo. Política: quem manda, por que manda, como manda. 2. ${ }^{a}$ ed. Rio de Janeiro, 1986, pp. 11-18. Um intelectual do humor assim definiria a ciência do poder: "A política, ora a política... a política, sinceramente, não passa de política.” Ver BRAGA, José Alberto. O Guia da Sobrevivência Política. Lisboa: Pergaminho, 1991.

${ }^{27}$ FREYRE, Gilberto. “Nota Metodológica.” In: Ordem e Progresso. $4^{a}$ ed. Rio de Janeiro: Record, 1990, pp. XXIII-XLVI. Em mais duas vezes, o presidente assumiria a mesma tese. Em seu diário, em 18 de março de 1939, ao mencionar um encontro que tivera com o seu biógrafo, André Carrazoni, assim anotou: "Prestei-lhe alguns esclarecimentos e disse-lhe que gosto mais de ser interpretado do que de me explicar." VARGAS, Getúlio. Op. cit., p. 209; e em carta a Samuel Wainer, no início de junho de 1951, escreveria para a primeira edição do jornal Última Hora: "Na realidade, gosto de ser interpretado, combatido, discutido ou louvado por espíritos isentos e desinteressados.” A carta está republicada na íntegra, juntamente com um rico acervo iconográfico, em WAINER, Samuel. Op. cit., entre as pp. 142-3. Sobre a tradição positivista na República, a partir dos políticos gaúchos, 
ver RODRIGUEZ, Ricardo Vélez. Castilhismo: uma filosofia da República. Porto Alegre: Escola Superior de Teologia São Lourenço de Brindes; Caxias do Sul, Universidade de Caxias do Sul, 1980; PINTO, Celi Regina J. Positivismo: um projeto político alternativo - (RS: 1889-1930). Porto Alegre: L\&PM Editores, 1986; e discussões mais recentes, em BOSI, Alfredo. "A arqueologia do Estado-Providência: sobre um enxerto de idéias de longa duração.” In A Dialética da Colonização. São Paulo: Cia. das Letras, 1992, pp. 273-307; e CARVALHO, José Murilo de. "A ortodoxia positivista no Brasil: um bolchevismo de classe média.” In Pontos e Bordados. op. cit., pp. 189-201.

${ }^{28}$ Fundação Getúlio Vargas/Centro de Pesquisa e Documentação de História Contemporânea do Brasil. A Revolução de 30 e seus Antecedentes: coletânea de fotografias organizada pelo CPDOC/FGV. Rio de Janeiro: Nova Fronteira, 1980, p. 193 (Arquivo CPDOC/Osvaldo Aranha, $31 / 10 / 1930)$.

${ }^{29}$ Em trabalho anterior, tentei explicitar alguns elementos cômicos das acusações "ideológicas" dirigidas contra os getulistas. FLORES, Elio Chaves. "Danações da República: getulistas, queremistas e pelegos.” Comunicação coordenada apresentada no XX Simpósio Nacional de História. ANPUH/UFSC, Florianópolis, 25 a 30 de julho de 1999.

${ }^{30}$ Ver ROSSET, Clément. Lógica do Pior. Rio de Janeiro: Espaço e Tempo, 1989, pp. 181-198. Para o autor, o "riso exterminador" significaria a vitória do caos sobre a aparência da ordem, o reconhecimento do acaso como verdade do que existe. Algo como "a hipóstase da aprovação" cuja metáfora mais apropriada seria a "estética do pior". Sobre a sensação tragi-cômica da República, ver "Prefácio à edição brasileira”, pp. 7-9.

Artigo recebido em 05/2000. Aprovado em 11/2000. 